\title{
The Proviral Load of the Bovine Leukosis Virus is Associated with the Polymorphisms of the BoLA-DRB3 Gene in the HartonDel Valle Breed
}

\author{
Darwin Hernandez*, Donicer Montes and Jaime De La Ossa-V \\ Faculty of Agricultural Sciences - University of Sucre, Sincelejo, Colombia; \\ darwin.hernandez@unisucre.edu.co,donicer.montes@unisucre.edu.co, jaimedelaossa@yahoo.com
}

\begin{abstract}
Objective: To associate the proviral load (PVL) of the bovine leukosis virus found in the Harton del Valle (HV) breed with the alleles of the BoLA-DRB3 gene. Methods: In $100 \mathrm{HV}$ animals, the PVL was evaluated using a real-time quantitative PCR and a TaqMan probe; the animals were classified according to their PVL in high proviral load (HPVL) or low proviral load (HPVL). Additionally, the animals were genotyped using the PCR-SBT method. The allele frequencies were estimated. Alleles were associated with HPVL (susceptible, S), LPVL (resistant, R) or neutral (N) using the Odds ratio (OR) statistic and the presence of common amino acids in the $\mathrm{R}$ and $\mathrm{S}$ alleles were determined. Findings: $A$ total of 22 alleles were found, the *1101 was the most frequent. High-frequency alleles accumulate $71.9 \%$. The PVL mean was 129740 copies/ $\mu \mathrm{g}$ of DNA. Seven alleles were associated with PVL, alleles *1002, *1601 and *1701 with HPVL (S) and alleles *0902, *1101, *20012 and *2703 with LPVL (R). The PVL of the alleles S and R was 516966 and 75074 copies/ $\mu g$ of DNA respectively. The allelic frequency R and genotype RR accumulated was higher than that of the alleles and genotypes $\mathrm{S}$. The amino acid Glu located in positions 70 of the DR $\beta$ peptide chain was common in the R alleles. Application/Improvements: The resistance to the PVL (LPVL) has particularities in each breed since the alleles according to the literature reports are not the same. These results can be used in selection programs in favor of the genes categorized here as $\mathrm{R}$, and thus, decrease the infection rate of the virus.
\end{abstract}

Keywords: Colombian Creole Cattle, Enzootic Bovine Leukosis, Genetic Resistance

\section{Introduction}

The enzootic bovine leukosis (EBL), is an infectious disease, the causative agent is the bovine leukosis virus (VLB) (BLV) is a B-lymphotropic oncogenic deltaretrovirus infecting cattle that shares common biological and structural features with the human T-cell leukemia virus I and II (HTLV-I and II) ${ }^{1}$. In the majority of cases, infection is asymptomatic but $30 \%$ of BLVinfected animals will develop a persistent lymphocytosis and less than $5 \%$ will progress to B-cell lymphoma or leukemia in animals older than 3 years, after a long period of latency characterized by the absence of viral replication ${ }^{2}$.

BLV tropism in the host is directed primarily to B cells, has a reverse transcriptase responsible for the synthesis of a DNA copy from viral RNA (provirus). The provirus is integrated into the DNA of host lymphoid cells ${ }^{3}$. Infected cells, surviving host immune response clearance, undergo a tight mRNA BLV transcriptional silencing, promoting cellular transformation and BLV persistence/replication through mitotic division ${ }^{4-5}$. 
The disease goes unnoticed, this fact masks the reality, the BVL generates productive and reproductive losses, besides, and it is immunosuppressive and allows the infection with other pathogens ${ }^{6}$. Worryingly, in heavily infected herds a drop in milk production to either individual/herd levels has been observed ${ }^{7-9}$, delayed-interval delivery is extended and the number of services per conception are increased ${ }^{10}$, milk protein decreases and the somatic cell count is increased ${ }^{11}$ followed by premature culling, and replacement of cows has been reported ${ }^{12-13}$.

Following the recommendations from OIE, many countries-initiated programs to control EBL with the aim of reducing economic losses and to reduce the spread of the disease by trade of breeding animals ${ }^{2}$. The disease prevention and control measures are directly linked to the herd management, the early elimination of infected animals is the most common ${ }^{13}$. The new strategies propose classifying animals from the proviral load (PVL) in peripheral blood ${ }^{14}$, eliminating animals with high load (HPVL) and allowing the reproduction of animals with low proviral load (LPVL), since it has been determined that the PVL is directly related to the level of infection in vivo ${ }^{5}$, is variable among individu$\mathrm{als}^{15-16}$ and apparently stable for extended periods of time ${ }^{17}$.

The genes that component the major histocompatibility complex or bovine leukocyte antigen (BoLA) has been associated with resistance and susceptibility to a wide range of diseases. The most common example of the relationship between the allelic variants BoLA gene has been established by the resistance to BLV, specifically with the class II gene BoLA-DRB $3^{13,15,18}$. Allelic variants located in the exon 2 encoding the peptide-binding cleft (PBC) of the surface molecule responsible for the presentation of peptides $^{13}$. The alleles of the DRB3 gene that code for conserved and polymorphic amino acid (AA) grouped into "pockets" side chain positions interacting with the antigenic peptide o be presented ${ }^{13,15}$.

Specific AA variants in the BoLA-DRB3 PBC have been associated with resistance to the development EBL $^{13,19-21}$. Previously we reported ${ }^{22-23}$ that Harton del Valle (HV) breed could be considered a slow progression of the disease, the infection pattern is different, it does not develop persistent lymphocytosis and maintains high antibody titers with VLB, despite having a high prevalence of the virus. However, the association of PVL with alleles of the DRB3 gene has not been carried out in HV. Therefore, the objective of this investigation was to associate the PVL found in the HV race with the alleles of the BoLA-DRB3 gene.

\section{Materials and Methods}

\subsection{Populations Evaluated and DNA Extraction}

In this research, 100 adult animals of the HV breed were used, from which DNA was extracted from blood, using the Wizard ${ }^{\oplus}$ Genomic DNA Purification Kit from Promega. Only BLV positive animals diagnosed by nested PCR were amplified by amplifying the viral env gene, as reported by ${ }^{23}$.

\subsection{DRB3 Genotyping}

Using the PCR-SBT methodology, in a final volume of $50 \mu \mathrm{l}$ with the primers DRB3FEW (5'-CGCTCCTGTGACCAGATCTATCC-3') and DRB3REV (5'-GGTGAGCGCGGGGGTG-3') ${ }^{24}$ at a concentration of $10 \mathrm{mM}, 25 \mathrm{ng}$ of DNA and $1 \mathrm{X}$ de MangoMix $^{\mathrm{TM}}$ (Bioline $\odot$ ) a fragment of approximately 281 was amplified. The thermal amplification cycle included a denaturation at $95^{\circ} \mathrm{C}$ for 5 minutes, followed by 37 cycles of $95^{\circ} \mathrm{C}$ for 45 seconds $61^{\circ} \mathrm{C}$ for 45 seconds and $72^{\circ} \mathrm{C}$ for 2 minutes and then a final extension step of $72^{\circ} \mathrm{C}$ for $5 \mathrm{~min}$ utes. The amplicons were sequenced in the MACROGEN Company, and edited using the GENEIOUS 6.1 program (Biomatters development team, USA). The genotypes were determined using HAPLOFINDER software (www.bioinfortmatics.roslin.ac.uk/haplofinder/haplofinder.py) ${ }^{25}$.

\subsection{PVL Evaluations}

Thisquantification wasperformedbyquantitativereal-time PCR (Q-PCR-RT). From a sample of known concentration (9.6x1010 copies/ $\mu \mathrm{g}$ of DNA), a standard curve was made from 0.1 to $1 \times 10^{7}$ copies $/ \mu g^{21-22}$. The quantification of PVL was performed by amplifying a $168 \mathrm{bp}$ fragment using the primers CoCoMo6-5'-MNMYCYKDRSYKSYKSAYYT CACCT-3'and CoCoMo81-5>-TACCTGMCSSCTKSCG GATAGCCGA-3', the TaqMan probe (5'-FAMCTCAGCTCTCGGTCCNFQ-MGB-3') 10ng of DNA, 2X of iTaq ${ }^{\text {TM }}$ Universal Probes Supermix, $200 \mathrm{mM}$ of each primer and $200 \mathrm{mM}$ of the FAM probe in a final volume of $10 \mu \mathrm{l}(21)$ a disease characterized by a highly extended course that often involves persistent lymphocytosis and culminates in B-cell lymphomas. BLV provirus remains integrated in cellular genomes, even in the absence of detectable BLV antibodies. Therefore, to understand the mechanism of BLV-induced leukemogenesis and carry out 
the selection of BLV-infected animals, a detailed evaluation of changes in proviral load throughout the course of disease in BLV-infected cattle is required. The aim of this study was to develop a new quantitative real-time polymerase chain reaction (PCR. Each standard of the curve and each sample were run in triplicate in a CFX96 "RealTime System" thermocycler (BIO-RAD ${ }^{\circledR}$ ) with the following program: $50^{\circ} \mathrm{C}$ for 2 minutes for the activation of the enzyme Uracil-DNA Glycosylase, $95^{\circ} \mathrm{C}$ for 10 minutes for the activation of the iTaq DNA polymerase, 85 cycles of 15 seconds at $95^{\circ} \mathrm{C}$ and 1 minute at $60^{\circ} \mathrm{C}$. The average of the cycle to which the cut-off point (CT: cycle threshold) is crossed was used to define the result. The critical classification value of animals in high load (HPVL) and a low proviral load (LPVL) was the median (1x105 copies/ $\mu \mathrm{g})$.

\subsection{Statistical Analysis}

The number of alleles and frequencies were caculated with the Arlequin ver 3.5 program ${ }^{26}$. The alleles BoLA-DRB3 were associated with HPVL or LPVL in case-control association analysis was calculated as the odds ratio (OR) with a confidence interval of $95 \%$. OR values close to 1 were considered as neutral $(\mathrm{N})$, while, OR values greater than 1 indicate that these alleles are at high risk and were considered susceptible (S) (negative association), OR values less than 1 indicate that these alleles are at low risk and were considered resistant (R) (positive association) ${ }^{13}$. An exact Fischer test was performed to determine significance of OR values using SAS software version $9.1^{23}$.

The allele frequencies accumulated of the alleles considered $\mathrm{R}, \mathrm{S}$, and $\mathrm{N}$ was estimated, as well as the accumulated genotypic frequencies, according to the classification of their alleles in N/N, N/R, N/S, R/R, R/S, and S/S.

\section{Results and Discussion}

In this investigation, 22 alleles were found in the BoLADRB3 gene, of which ${ }^{\star} 1101$ was the most frequent $(16.88 \%)$. In this same breed, the number of alleles reported was 24 alleles ${ }^{27}, 27$ alleles ${ }^{23}$ and $37^{28}$ alleles; additionally, these reports establish that the allele ${ }^{\star} 1101$ is the most frequent, which agrees with the present work. In Table 1, the allele frequencies calculated can be observed.

The alleles ${ }^{\star} 20012,{ }^{\star} 0902,{ }^{\star} 1701,{ }^{\star} 1002,{ }^{\star} 2703,{ }^{\star} 1501$ and ${ }^{\star} 25011$ showed allelic frequencies greater than $5 \%$ (Table 1), the remaining 14 alleles represent $28.13 \%$ of the accumulated frequencies.
In others autochthonous breads the number of alleles found was 22 in the Japanese Negro ${ }^{29}, 28$ in Hanwoo $^{30}, 35$ in Yacumeno ${ }^{27}$ and 71 in the native of the Philippines ${ }^{31}$, while, in the breed Holstein's study of this gene has been wider with 18 alleles in Holstein from Argentina ${ }^{32}$, 39 in Brazil $^{33}, 37$ in Holstein Irani ${ }^{34}, 17$ in Holstein of Japan ${ }^{29}$ and in Holstein different South American countries from 20 to 33 alleles $^{35}$. The above shows the high genetic variation that this gene presents.

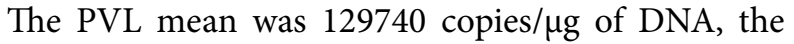
highest value was found in the animals carrying the allele ${ }^{\star} 1002(1112378$ copies $/ \mu g)$ and the lowest in the carriers of the allele ${ }^{\star} 2703$ (733 copies/ $\mu \mathrm{g}$ ). The critical PVL value to consider the allele as HPVL or LPVL was the median, estimated at 6533 copies/ $\mu \mathrm{g}$ of DNA. In that order of ideas, 11 alleles were considered HPVL of which only three $\left({ }^{\star} 1002,{ }^{\star} 1601\right.$ and $\left.{ }^{\star} 1701\right)$ were significantly associated with HPVL and were considered as susceptible (S). The PVL of the alleles associated with HPVL was 516966 copies/ $\mu \mathrm{g}$ of DNA. While, 11 alleles were considered LPVL of which four $\left({ }^{\star} 0902,{ }^{\star} 1101,{ }^{\star} 20012\right.$ and $\left.{ }^{\star} 2703\right)$ were significantly associated with LPVL and were considered as resistant (R) and the PVL of these was from 75074

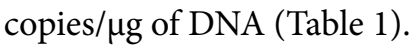

The cumulative frequency of the alleles associated with LPVL was $47.5 \%$, followed by the frequency of the neutral alleles (35\%) and by alleles associated with HPVL (17.5\%). Alleles ${ }^{\star} 0902$ and ${ }^{\star} 20012$ associated with LPVL had HPVL; in contrast, none of the alleles associated with HPVL presented LPVL. The genotype frequencies according to the category of each allele and its PVL are presented in Table 2.

As in this report, the allele ${ }^{\star} 0902$ has-been associated with LPVL in Holstein ${ }^{19,36}$, Argentine Holstein ${ }^{13,32,37}$ and Japanese Black ${ }^{36,38}$. Whereas, in the other alleles associated here with LPVL, ${ }^{\star} 1101$ has-been associated with the susceptibility to the development of persistent lymphocytosis $^{19}$ but also, with the low infection rate of Babesia bigemina as well as the allele ${ }^{\star} 20012^{39}$. On the other hand, the allele ${ }^{\star} 2703$ has-been associated with a high infection rate of Babesia bigemina ${ }^{39}$. This is the first association report of alleles ${ }^{\star} 20012$ and ${ }^{\star} 2703$ with LPVL. The alleles associated with HPVL reported in the literature include the alleles ${ }^{\star} 0101,{ }^{\star} 1001$ and ${ }^{\star} 1101{ }^{\star} 1201,{ }^{\star} 1501,{ }^{\star} 1503$ and ${ }^{\star} 1601^{13,15,19,36-37}$, of which none of them presented here the same classification. In particular, the allele ${ }^{\star} 1701$ here associated with HPVL, was associated with LPVL by ${ }^{37}$. 
Table 1. Allelic frequencies, proviral load (PVL), OR value, confidence interval, Fischer P-value and classification of alleles found in race HV

\begin{tabular}{|c|c|c|c|c|c|c|c|}
\hline \multirow{2}{*}{$\begin{array}{l}\text { Allele } \\
{ }^{*} 0101\end{array}$} & \multirow{2}{*}{$\begin{array}{l}\text { Frequency } \\
1.88 \%\end{array}$} & \multirow{2}{*}{ 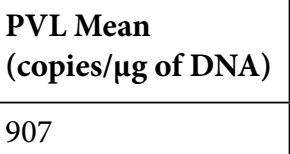 } & \multirow{2}{*}{$\frac{\text { OR }}{1.48}$} & \multicolumn{2}{|c|}{ IC (95\%) } & \multirow{2}{*}{$\begin{array}{l}\text { Fischer P-value } \\
0.2476\end{array}$} & \multirow{2}{*}{$\begin{array}{l}\text { Classification } \\
\mathrm{N}\end{array}$} \\
\hline & & & & 0.77 & 7.45 & & \\
\hline${ }^{\star} 0501$ & $3.75 \%$ & 52571 & 1.88 & 1.07 & 9.45 & 0.2143 & $\mathrm{~N}$ \\
\hline${ }^{\star} 0701$ & $1.25 \%$ & 2453 & 1.44 & 1.01 & 9.40 & 0.4984 & $\mathrm{~N}$ \\
\hline${ }^{*} 0902$ & $11.25 \%$ & 7748 & 0.27 & 0.01 & 0.57 & 0.0004 & $\mathrm{R}$ \\
\hline${ }^{\star} 1002$ & $5.63 \%$ & 1112378 & 4.32 & 2.09 & 6.99 & 0.0173 & $S$ \\
\hline${ }^{\star} 1101$ & $16.88 \%$ & 5318 & 0.32 & 0.11 & 0.51 & 0.0001 & $\mathrm{R}$ \\
\hline${ }^{*} 1104$ & $2.50 \%$ & 4391 & 1.53 & 1.05 & 3.96 & 0.1226 & $\mathrm{~N}$ \\
\hline *14011 & $0.63 \%$ & 1084 & 1.38 & 1.15 & 7.41 & 1.0000 & $\mathrm{~N}$ \\
\hline${ }^{*} 1501$ & $5.63 \%$ & 353790 & 1.08 & 0.98 & 2.99 & 1.0000 & $\mathrm{~N}$ \\
\hline${ }^{*} 1601$ & $4.38 \%$ & 266037 & 6.42 & 4.09 & 8.75 & 0.0045 & S \\
\hline${ }^{*} 1701$ & $7.50 \%$ & 172482 & 7.41 & 5.01 & 9.89 & 0.0230 & $S$ \\
\hline$\star 20012$ & $13.75 \%$ & 46495 & 0.71 & 0.45 & 0.99 & 0.0031 & $\mathrm{R}$ \\
\hline$\star 2006$ & $0.63 \%$ & 2306 & 1.38 & 1.15 & 7.41 & 1.0000 & $\mathrm{~N}$ \\
\hline$\star 2201$ & $1.88 \%$ & 96965 & 1.96 & 0.20 & 8.94 & 1.0000 & $\mathrm{~N}$ \\
\hline *25011 & $5.63 \%$ & 701540 & 0.59 & 0.13 & 1.90 & 0.5015 & $\mathrm{~N}$ \\
\hline$\star 25012$ & $0.63 \%$ & 10022 & 1.38 & 1.15 & 7.41 & 1.0000 & $\mathrm{~N}$ \\
\hline$\star 2703$ & $5.63 \%$ & 733 & 1.78 & 1.07 & 9.82 & 0.0010 & $\mathrm{R}$ \\
\hline${ }^{*} 2802$ & $1.88 \%$ & 1580 & 1.48 & 0.77 & 7.45 & 0.2476 & $\mathrm{~N}$ \\
\hline$\star 2902$ & $2.50 \%$ & 9325 & 1.53 & 1.05 & 3.96 & 0.1226 & $\mathrm{~N}$ \\
\hline${ }^{*} 3501$ & $0.63 \%$ & 2950 & 1.38 & 1.15 & 7.41 & 1.0000 & $\mathrm{~N}$ \\
\hline$* 3601$ & $2.50 \%$ & 1991 & 1.53 & 1.05 & 3.96 & 0.1226 & $\mathrm{~N}$ \\
\hline *3901 & $3.13 \%$ & 1207 & 1.88 & 1.07 & 9.45 & 0.2143 & $\mathrm{~N}$ \\
\hline
\end{tabular}

Table 2. Accumulated genotypic frequency according to the classification given to each allele and the average PVL in each genotype

\begin{tabular}{|c|c|c|c|c|c|c|}
\hline Item & $\mathbf{N} / \mathbf{N}$ & N/R & $\mathrm{N} / \mathrm{S}$ & $\mathbf{R} / \mathbf{R}$ & $\mathrm{R} / \mathrm{S}$ & S/S \\
\hline Frequency (\%) & 25 & 22.5 & 17.5 & 18.8 & 7.5 & 8.7 \\
\hline PVL Mean (copies/ $\mu \mathrm{g}$ of DNA) & 82872 & 68599 & 155221 & 15074 & 230170 & 516966 \\
\hline
\end{tabular}

The amino acids located in positions 70 and 71 of the DR $\beta$ peptide chain (motif ER: Glu-Arg) have been associated with low proviral load ${ }^{13,19}$, the alleles considered here as resistant have the RR motif in these same positions, whereas, the susceptibles have the amino acids Ala, Glu and Lys in position 70 and Arg in position 71.

Other genes/alleles associated with PVL are BoLADQA1 ${ }^{\star} 0204$ that associates LPVL and that allele
BoLA-DQA1 ${ }^{\star} 10012$ that is associated with $\mathrm{HPVL}^{36}$. It also indicates that the DRB3-DQA1 haplotypes can be correlated with the proviral load, thus the $\mathrm{DRB}^{*} 0902-\mathrm{DQA} 1^{*} 0204$ and DRB $3{ }^{*} 1101-\mathrm{DQA1}{ }^{\star} 10011$ haplotypes were associated with LPVL and the $\mathrm{DRB}^{\star}{ }^{\star} 1601-\mathrm{DQA1}{ }^{\star} 10012$ haplotype with $\mathrm{HPVL}^{36}$.

Through other genotyping and association methodologies, using SNP50 K BeadChip, three SNPs were 
associated with LPVL, two located on chromosome $23^{40}$, in another study using BovineSNP50 v2 BeadChip, 24 SNPs located on chromosome 23 were associated with the LPVL ${ }^{41}$, genes close to this region include immune response, cell cytoskeletal reorganization, and modeling of the extracellular matrix ${ }^{42}$.

Of the homozygous genotypes, $\mathrm{N} / \mathrm{N}$ was the most frequent followed by $\mathrm{R} / \mathrm{R}$ and $\mathrm{S} / \mathrm{S}$, while in the heterozygous genotypes; the N/R presented the highest frequency followed by N/S and R/S (Table 2). Using this same genotyping system, it has been reported that the individuals $\mathrm{N} / \mathrm{N}$ and $\mathrm{S} / \mathrm{S}$ are the most and least frequent respectively against the infection against the $\mathrm{EBL}^{22-22,37}$.

The S/S individuals had 34 times more PVL than the $\mathrm{R} / \mathrm{R}$ individuals, this genotype had the lowest PVL, the genotypes that have at least one allele $\mathrm{N}$ allele had low proviral loads, even more, when it was homozygous or with the allele $\mathrm{A}$. The $\mathrm{R} / \mathrm{S}$ genotype had lower proviral load than the $\mathrm{S} / \mathrm{S}$ genotype. These results suggest that low maintenance of the proviral load can be improved in heterozygous individuals, also called heterozygous advantage, as has been amply demonstrated against mastitis ${ }^{25,43}$ and $\mathrm{EBL}^{13,23,36}$.

Animals with LPVL disseminate EBL less frequently ${ }^{44}$; in addition, good PVL is a good predictor of its development ${ }^{23}$, which indicates that selection in favor of alleles associated with LPVL could help control of the EBL.

\section{Conclusions}

The genetic diversity of the DRB3 gene in HV is high, determined by the number of genes and their frequencies. Seven of twenty-two alleles were associated with PVL, alleles ${ }^{\star} 1002,{ }^{\star} 1601$ and ${ }^{\star} 1701$ with HPVL and alleles ${ }^{\star} 0902,{ }^{\star} 1101$, ${ }^{\star} 20012$ and ${ }^{\star} 2703$ with LPVL. The PVL and the R alleles were significantly lower than in the $\mathrm{S}$ alleles. The cumulative frequency of the $S$ alleles and the SS genotype was lower compared to the $\mathrm{R}$ alleles and genotypes with at least one resistance allele. As in other investigations, the presence of common amino acids between alleles with the same classification (R or S) was evidenced. These results can be used in selection programs in favor of the genes categorized here as $\mathrm{R}$, and thus, decrease the infection rate of the virus.

\section{References}

1. Driessche BV, Rodari A, Delacourt N, Fauquenoy S, Vanhulle C, Burny A. Characterization of new RNA polymerase III and RNA polymerase II transcriptional promoters in the Bovine Leukemia Virus genome. Scientific Reports. 2016; 6:31125. https://doi.org/10.1038/srep31125 PMid:27545598 PMCid:PMC4992882

2. EFSA Panel on Animal Health and Welfare. Enzootic bovine leukosis. EFSA Journal. 2015; 13(7):4188. https:// doi.org/10.2903/j.efsa.2015.4188

3. van den Heuvel M, Portetelle D, Jefferson B, Jacobs RM. Adaptation of a sandwich enzyme-linked immunosorbent assay to determine the concentration of bovine leukemia virus p24 and optimal conditions for p24 expression in short-term cultures of peripheral blood mononuclear cells. Journal of Virological Methods. 2003; 111(1):61-7. https:// doi.org/10.1016/S0166-0934(03)00148-4

4. Gillet NA, Hamaidia M, Brogniez A de, Gutierrez G, Renotte N, Reichert M. Bovine Leukemia Virus Small Noncoding RNAs Are Functional Elements That Regulate Replication and Contribute to Oncogenesis In Vivo. PLOS Pathogens. 2016; 12(4):e1005588. https://doi.org/10.1371/journal. ppat.1005588 PMid:27123579 PMCid:PMC4849745

5. Jimba M, Takeshima S, Murakami H, Kohara J, Kobayashi N, Matsuhashi T. BLV-CoCoMo-qPCR: a useful tool for evaluating bovine leukemia virus infection status. BMC Veterinary Research. 2012; 8(1):167. https:// doi.org/10.1186/1746-6148-8-167 PMid:22995575 PMCid:PMC3489618

6. Sandez N, Ilieva D, Sizov I, Rusenova N, Iliev E. Prevalence of enzootic bovine leukosis in the Republic of Bulgaria in 1977-2004. VeterinarskiArhiv. 2006; 76(3):263-8.

7. Erskine RJ, Bartlett PC, Byrem TM, Render CL, Febvay C, Houseman JT. Herd-level determinants of bovine leukaemia virus prevalence in dairy farms. Journal of Dairy Research. 2012; 79(4):445-50. https://doi.org/10.1017/ S0022029912000520 PMid:22963749

8. Norby B, Bartlett P, Byrem T, Erskine R. Effect of infection with bovine leukemia virus on milk production in Michigan dairy cows. Journal of Dairy Science. 2016; 99(3):2043-52. https://doi.org/10.3168/jds.2015-10089 PMid:26723124

9. Cadavid L. Impacto del Leucosis Viral Bovina en la produccion de leche. Colombia: Universidad Nacional de Colombia. 2012.

10. Santamaria J. Estudio de parametros productios y reproductivos en vacas seropositivas y seronegativas al virus de la leucosis bovina (BLV) entreshatos de produccion lechera. Ecuador: Escuela Politecnica del Ejercito. Pichincha. 2014.

11. Szewczuk M, Zych S, Katafiasz S. Diagnosis of the bovine leukaemia virus infection in Polish Holstein-Friesian cows and comparison of their milk productivity. Acta Veterinaria Brno. 2012; 81(4):353-8. https://doi.org/10.2754/ avb201281040353

12. Bartlett PC, Norby B, Byrem TM, Parmelee A, Ledergerber JT, Erskine RJ. Bovine leukemia virus and cow longev- 
ity in Michigan dairy herds. Journal of Dairy Science. 2013; 96(3):1591-7. https://doi.org/10.3168/jds.2012-5930 PMid:23332856

13. Carignano HA, Beribe MJ, Caffaro ME, Amadio A, Nani JP, Gutierrez G. BOLA-DRB3 gene polymorphisms influence bovine leukaemia virus infection levels in Holstein and Holstein $\times$ Jersey crossbreed dairy cattle. Animal Genetics. 2017; 48(4):420-30. https://doi.org/10.1111/age.12566 PMid:28568505

14. Juliarena MA, Barrios CN, Ceriani MC, Esteban EN. Hot topic: Bovine leukemia virus (BLV) - infected cows with low proviral load are not a source of infection for BLV-free cattle. Journal of Dairy Science. 2016; 99(6):4586-9. https:// doi.org/10.3168/jds.2015-10480 PMid:27085403

15. Juliarena MA, Gutierrez SE, Ceriani C. Determination of proviral load in bovine leukemia virus-infected cattle with and without lymphocytosis. American Journal of Veterinary Research. 2007; 68(11):1220-5. https://doi. org/10.2460/ajvr.68.11.1220 PMid:17975977

16. Gutierrez G, Alvarez I, Politzki R, Lomonaco M, Dus Santos MJ, Rondelli F. Natural progression of Bovine Leukemia Virus infection in Argentinean dairy cattle. Veterinary Microbiology. 2011; 151(3-4):255-63. https:// doi.org/10.1016/j.vetmic.2011.03.035 PMid:21550733

17. Florins A, Gillet N, Asquith B, Boxus M, Burteau C, Twizere J-C. Cell dynamics and immune response to BLV infection: a unifying model. Frontiers in Bioscience. 2007; 12:152031. https://doi.org/10.2741/2165 PMid:17127399

18. Brujeni GN, Ghorbanpour R, Esmailnejad A. Association of BoLA-DRB3.2 Alleles with BLV Infection Profiles (Persistent Lymphocytosis/Lymphosarcoma) and Lymphocyte Subsets in Iranian Holstein Cattle. Biochemical Genetics. 2016; 54(2):194-207. https://doi.org/10.1007/s10528-016-9712-6 PMid:26782666

19. Xu A, van Eijk MJ, Park C, Lewin HA. Polymorphism in BoLA-DRB3 exon 2 correlates with resistance to persistent lymphocytosis caused by bovine leukemia virus. The Journal of Immunology. 1993; 151(12):6977-85. PMid:8258704

20. Mirsky ML, Olmstead C, Da Y, Lewin HA. Reduced bovine leukaemia virus proviral load in genetically resistant cattle. Animal Genetics. 1998; 29(4):245-52. https://doi. org/10.1046/j.1365-2052.1998.00320.x PMid:9745662

21. Jimba M, Takeshima S, Matoba K, Endoh D, Aida Y. BLVCoCoMo-qPCR: Quantitation of bovine leukemia virus proviral load using the CoCoMo algorithm. Retrovirology. 2010; 7:91. https://doi.org/10.1186/1742-4690-7-91 PMid:21044304 PMCid:PMC2988707

22. Hernandez D, Mu-oz J, Alvarez L. Dynamics of Bovine leukosis in creole cattle Harton del Valle in natural infection. Archivos de Zootecnia. 2016; 65(251):365-73. https://doi. org/10.21071/az.v65i251.698
23. Hernandez D, Montes D, Alvarez LA. Association of BolaDRB3.2 Alleles with Enzootic Bovine Leukosis: Profiles BLV Infection, Persistent Lymphocytosis and Antibody Production in Harton Del Valle Cattle. Indian Journal of Science and Technology. 2018; 11(24):1-14. https://doi. org/10.17485/ijst/2018/v11i24/128164

24. Takeshima S-N, Matsumoto Y, Miyasaka T, AraingaRamirez M, Saito H, Onuma M, et al. A new method for typing bovine major histocompatibility complex class II DRB3 alleles by combining two established PCR sequencebased techniques. Tissue Antigens. 2011; 78(3):208-13. https://doi.org/10.1111/j.1399-0039.2011.01708.x PMid:21623735

25. Baxter R, Hastings N, Law A, Glass EJ. A rapid and robust sequence-based genotyping method for BoLA-DRB3 alleles in large numbers of heterozygous cattle. Animal Genetics. 2008; 39(5):561-3. https://doi.org/10.1111/j.13652052.2008.01757.x PMid:18637877

26. Excoffier L, Lischer HEL. Arlequin suite ver 3.5: a new series of programs to perform population genetics analyses under Linux and Windows. Molecular Ecology Resources. 2010; 10(3):564-7. https://doi.org/10.1111/j.17550998.2010.02847.x PMid:21565059

27. Giovambattista G, Takeshima S, Ripoli MV, Matsumoto Y, Franco LAA, Saito H, et al. Characterization of bovine MHC DRB3 diversity in Latin American Creole cattle breeds. Gene. 2013; 519(1):150-8. https://doi.org/10.1016/j. gene.2013.01.002 PMid:23333729

28. Hernandez D, Mu-oz J, Alvarez L. Genetic diversity of BoLA-DRB3 gene in Colombian creole Harton del Valle cattle. Revista CES de Medicina Veterianaria y Zootecnia. 2015; 10(1):18-30.

29. Miyasaka T, Takeshima S, Matsumoto Y, Kobayashi N, Matsuhashi T, Miyazaki Y. The diversity of bovine MHC class II DRB3 and DQA1 alleles in different herds of Japanese Black and Holstein cattle in Japan. Gene. 2011; 472(1-2):42-9. https://doi.org/10.1016/j.gene.2010.10.007 PMid:20965236

30. Lee B-Y, Hur T-Y, Jung Y-H, Kim H. Identification of BoLA-DRB3.2 alleles in Korean native cattle (Hanwoo) and Holstein populations using a next generation sequencer. Animal Genetics. 2012; 43(4):438-41. https://doi. org/10.1111/j.1365-2052.2011.02264.x PMid:22497659

31. Takeshima SN, Miyasaka T, Polat M, Kikuya M, Matsumoto Y, Mingala CN. The great diversity of major histocompatibility complex class II genes in Philippine native cattle. Meta Gene. 2014; 2:176-90. https://doi.org/10.1016/j. mgene.2013.12.005 PMid:25606401 PMCid:PMC4287811

32. Farias MVN, Caffaro ME, Lendez PA, Passucci J, Poli M, Ceriani MC, et al. A novel association of BoLA DRB3 alleles in BLV infected cattle with different proviral loads. 
Brazilian Journal of Veterinary Research and Animal Science. 2017; 54(3):215-24. https://doi.org/10.11606/ issn.1678-4456.bjvras.2017.123769

33. Vilaca L, Diniz W, Melo T, Oliveira J, Guido S, Brito C, et al. BoLA-DRB3 gene polymorphisms in 5/8 Girolando and Holstein dairy. Archivos de Zootecnia. 2016; 65(249):7-11.

34. Gholamreza N, Ghorbanpour R, Esmailnejad A. Association of BoLA-DRB3.2 Alleles with BLV Infection Profiles (Persistent Lymphocytosis/Lymphosarcoma) and Lymphocyte Subsets in Iranian Holstein Cattle. Biochemical Genetics. 2016; 54(2):194-207. https://doi.org/10.1007/ s10528-016-9712-6 PMid:26782666

35. Takeshima S-N, Giovambattista G, Okimoto N, Matsumoto Y, Rogberg-Mu-oz A, Acosta TJ. Characterization of bovine MHC class II DRB3 diversity in South American Holstein cattle populations. Tissue Antigens. 2015; 86(6):419-30. https://doi.org/10.1111/tan.12692 PMid:26514650

36. Miyasaka T, Takeshima S-, Jimba M, Matsumoto Y, Kobayashi N, Matsuhashi T. Identification of bovine leukocyte antigen class II haplotypes associated with variations in bovine leukemia virus proviral load in Japanese Black cattle. Tissue Antigens. 2013; 81(2):72-82. https://doi. org/10.1111/tan.12041 PMid:23216331

37. Juliarena MA, Poli M, Sala L, Ceriani C, Gutierrez S, Dolcini G. Association of BLV infection profiles with alleles of the BoLADRB3.2 gene. Animal Genetics. 2008; 39(4):432-8. https:// doi.org/10.1111/j.1365-2052.2008.01750.x PMid:18573126

38. Hayashi T, Mekata H, Sekiguchi S, Kirino Y, Mitoma S, Honkawa K, et al. Cattle with the BoLA class II DRB3*0902 allele have significantly lower bovine leukemia proviral loads. The Journal of Veterinary Medical Science.
2017; 79(9):1552-5. https://doi.org/10.1292/jvms.16-0601 PMid:28757522 PMCid:PMC5627326

39. Bola-os I, Hernandez D, Alvarez L. Asociacion de los alelos del gen BoLA-DRB3 con la infeccion natural de Babesia sppen el ganado criollo Harton del Valle. Archivos de Zootecnia. 2017; 66(253):113-20.

40. Takeshima S, Sasaki S, Meripet P, Sugimoto Y, Aida Y. Single nucleotide polymorphisms in the bovine MHC region of Japanese Black cattle are associated with bovine leukemia virus proviralload. Retrovirology. 2017; 14(1):24. https:// doi.org/10.1186/s12977-017-0348-3 PMid:28376881 PMCid:PMC5379713

41. Carignano HA, Roldan DL, Beribe MJ, Raschia MA, Amadio A, Nani JP. Genome-wide scan for commons SNPs affecting bovine leukemia virus infection level in dairy cattle. BMC Genomics. 2018; 19(1):142. https://doi.org/10.1186/ s12864-018-4523-2 PMid:29439661 PMCid:PMC5812220

42. Abdalla EA, Pe-Agaricano F, Byrem TM, Weigel KA, Rosa GJM. Genome-wide association mapping and pathway analysis of leukosis incidence in a US Holstein cattle population. Animal Genetics. 2016; 47(4):395-407. https://doi. org/10.1111/age.12438 PMid:27090879

43. Takeshima S, Matsumoto Y, Chen J, Yoshida T, Mukoyama H, Aida Y. Evidence for cattle major histocompatibility complex (BoLA) class II DQA1 gene heterozygote advantage against clinical mastitis caused by Streptococci and Escherichia species. Tissue Antigens. 2008; 72(6):525-31. https://doi. org/10.1111/j.1399-0039.2008.01140.x PMid:19000149

44. Mekata H, Yamamoto M, Hayashi T, Kirino Y, Sekiguchi S, Konnai S. Cattle with a low bovine leukemia virus proviral load are rarely an infectious source. Japanese Journal of Veterinary Research. 2018; 66(3):157-63. 